\title{
The late flowering of invasive species contributes to the increase of Artemisia allergenic pollen in autumn: an analysis of 25 years of aerobiological data (1995-2019) in Trentino-Alto Adige (Northern Italy)
}

\author{
Antonella Cristofori 1 - Edith Bucher - Michele Rossi - Fabiana Cristofolini • \\ Veronika Kofler • Filippo Prosser • Elena Gottardini
}

Received: 30 April 2020/Accepted: 18 September 2020/Published online: 2 October 2020

(C) The Author(s) 2020

\begin{abstract}
Artemisia pollen is an important aeroallergen in late summer, especially in central and eastern Europe where distinct anemophilous Artemisia spp. produce high amounts of pollen grains. The study aims at: (i) analyzing the temporal pattern of and changes in the Artemisia spp. pollen season; (ii) identifying the Artemisia species responsible for the local airborne pollen load.

Daily pollen concentration of Artemisia spp. was analyzed at two sites (BZ and SM) in Trentino-Alto Adige, North Italy, from 1995 to 2019.

The analysis of airborne Artemisia pollen concentrations evidences the presence of a bimodal curve, with two peaks, in August and September, respectively. The magnitude of peak concentrations varies across the studied time span for both sites: the
\end{abstract}

Electronic supplementary material The online version of this article (https://doi.org/10.1007/s10453-020-09663-7) contains supplementary material, which is available to authorized users.

A. Cristofori $(\varangle) \cdot$ F. Cristofolini · E. Gottardini Fondazione Edmund Mach, via E. Mach 1, 38010 San Michele All'Adige, Trento, Italy e-mail: antonella.cristofori@fmach.it

E. Bucher · M. Rossi · V. Kofler

Agency for Environment and Climate Protection, Via

Sottomonte, 2, Laives, Bolzano 39055, Italy

F. Prosser

Fondazione Museo Civico Di Rovereto, Borgo Santa

Caterina 41, Rovereto, Trento 38068, Italy maximum concentration at the September peak increases significantly for both the BZ $(p<0.05)$ and SM $(p<0.001)$ site. The first peak in the pollen calendar is attributable to native Artemisia species, with $A$. vulgaris as the most abundant; the second peak is mostly represented by the invasive species $A$. апnиa and $A$. verlotiorum (in constant proportion along the years), which are causing a considerable increase in pollen concentration in the late pollen season in recent years.. The spread of these species can affect human health, increasing the length and severity of allergenic pollen exposure in autumn, as well as plant biodiversity in both natural and cultivated areas, with negative impacts on, e.g., Natura 2000 protected sites and crops.

Keywords Aerobiology · Mugwort · Pollen · Allergy $\cdot$ Temporal trend

\section{Introduction}

The genus Artemisia (Compositae family) comprises about 500 species worldwide, with its principal distribution in the northern hemisphere. There are 75 known Artemisia species in Europe (https://eunis.eea. europa.eu/, accessed July 3, 2020), and at least 10 species occur in the Italian region of Trentino-Alto Adige (Wilhalm et al. 2006; Prosser et al. 2019). The genus shows a wide range of life forms, from small 
alpine specimens up to 2-m-high herbaceous plants or shrubs at lower altitudes.

For pollination to be successful, the anemophilous Artemisia species are required to produce high amounts of pollen grains. The quantity of pollen grains produced varies between different species but also between different specimens of the same species. According to the study by Bogawski et al. (2016) conducted in Poland, Artemisia vulgaris and Artemisia absinthium produce more pollen compared to Artemisia campestris, due to a higher number of pollen grains per single flower and/or to a higher number of single flowers per inflorescence. Piotrowska (2008) calculated, for example, that one flower of Artemisia vulgaris may produce up to nearly 50,000 pollen grains, while Bogawski et al. (2016) determined values of 4000-16,000 pollen grains.

Airborne pollen concentrations decrease rapidly along with the height above ground level (Spieksma et al. 2000; Rojo et al. 2019a, b). For this reason, pollen exposure might be underestimated when the pollen trap is located on the roof of a building, usually 15-20 m high. Pollen concentrations could be considerably higher at ground level, particularly near areas with high density of Artemisia flowering plants. On the other hand, this fact implies that the measured airborne pollen concentrations mainly represent the Artemisia species growing in the surroundings, even if the influence of remote sources cannot be excluded (Qin et al. 2019).

Although the seasonal total values of Artemisia pollen reach only $0.5-5 \%$ of the annual pollen integral (Spieksma and von Wahl 1991), this pollen is considered to be an important aeroallergen in late summer, especially in central and Eastern Europe. In Poland, for example, Artemisia ranks third among the most common causes of pollen allergy, after grasses and birch (Weryszko-Chmielewska et al. 2018). Sensitization rates in Europe vary from $6.7 \%$ in Italy up to $44.3 \%$ in Hungary (Burbach et al. 2009). Artemisia spp. pollen is known as the most important outdoor pollen-allergen in the autumn season even in China, causing allergic rhinitis and asthma (Gao et al. 2019).

Artemisia species are short-day plants generally flowering in late summer and autumn. The vegetative growth occurs during the warm summer period, and the generative development is induced after the day length decreases and the summer temperatures have reached their peak (Spieksma et al. 1989). While in central Europe the pollen season generally displays a unimodal pattern for this pollen taxa (Grewling et al. 2015), this is not the case in southern and southeast Europe. Here, different ecological and phenological features of different species determine a bimodal or multimodal curve of the Artemisia pollen season. In Italy, after the first peak in August, mainly due to Artemisia vulgaris and, in rural environments, also to Artemisia campestris and other species, a second peak occurs in late September, which is mostly attributable to the invasive species Artemisia annиa and Artemisia verlotiorum (Caramiello et al. 1989). In southeast Europe, Artemisia maritima and Artemisia scoparia are suspected to be the major source for the second pollen peak in mid-September (Grewling et al. 2012). Whereas Artemisia vulgaris is widely distributed in the whole northern hemisphere, this is not the case for the late flowering species. Artemisia аппиа originates in Asia and East Europe, and since the last century, it became widely naturalized in Central and Southern Europe (Caramiello et al. 1989). In Italy, it has been cultivated since the beginning of the nineteenth century; step by step, it spread out and found its habitat, mainly in ruderal urban areas. Artemisia verlotiorum comes from Southeast China; it has been introduced in Europe in the second half of the nineteenth century and shows an ongoing expansion (Caramiello et al. 1989; unpublished personal observations in Trentino-Alto Adige).

In southeastern Spain, the Artemisia pollen season shows three peaks and extends well into winter, due to the late flowering of the endemic species Artemisia barrelieri (Giner et al. 1998; Cariñanos et al. 2010).

Artemisia spp. plants are characterized by inconspicuous flowers assembled in capitula, no nectar production and dry, microechinate, trizonocolporate pollen grains. Under a light microscope the thick, columellate exine appears "semilunar" in the optical section, a further feature of the "Artemisia pollen type."

Species differentiation based on pollen morphology remains difficult. Nevertheless, differences in pollen grain dimension combined with a knowledge on local species distribution and their phenology makes it possible to assign the corresponding species to the relevant aerobiological samples. Following this approach, Caramiello et al. (1989) were able to distinguish the bigger pollen grains of $A$. verlotiorum 

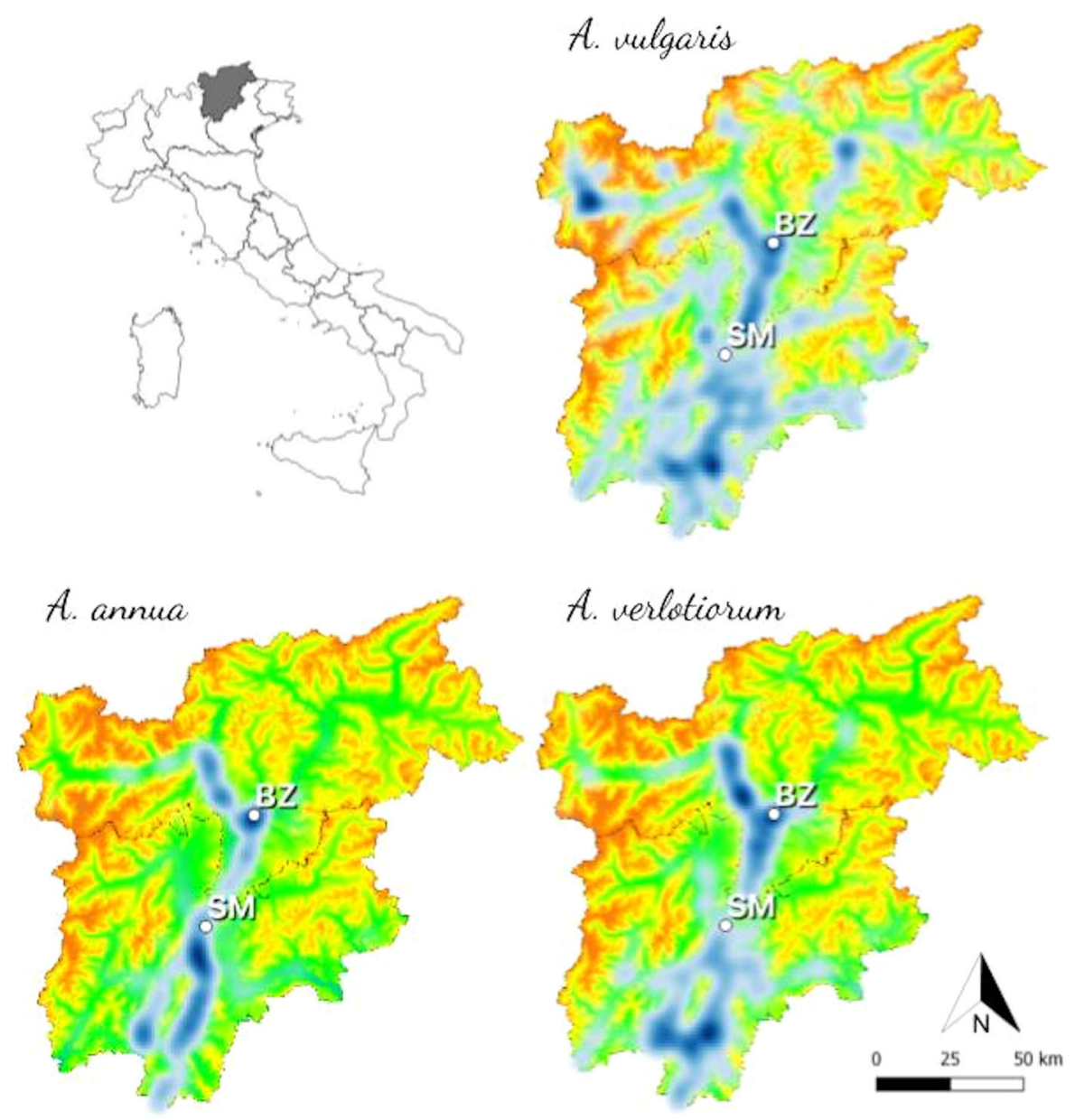

Fig. 1 Spatial distribution of selected Artemisia species for the Trentino-Alto Adige region. Top left, the location of TrentinoAlto Adige in Italy. Maps, built on an altitudinal raster image (i.e., green-low altitude to brown-high altitude), describe the

from that of the contemporaneously late flowering species A. аппиа in aerobiological samples. Airborne pollen data can be used as a bioindicator for the anemophilous flora and provide information about the effect of ongoing changes in the environment (Cariñanos et al. 2013). For example, A. verlotiorum, showing a high propagation potential due to its vegetative reproduction by stolons, invades cultivated areas and fallow lands. Because of its plant height and stand density, this species may constitute a strong competitor for other plants (www.infoflora.ch; Banfi and Galasso et al. 2010). Long-term pollen data are therefore of interest also in order to study the behavior and response to global warming of plant species (Fernández-Llamazares et al. 2014) and to foresee

distribution of relevant Artemisia species, shown as heat maps (blue scale, where darker blue is the more dense area). The white points represent the two aerobiological monitoring sites of Bolzano (BZ) and San Michele all'Adige (SM)

possible pollen season changes. This paper evaluates Artemisia pollen concentration data gathered in 25 years (1995-2019) of aerobiological monitoring carried out at two sites in Trentino-Alto Adige, an Alpine region in Northern Italy. The aims of the study are:

(i) Analyzing the temporal pattern of and changes in the Artemisia spp. pollen season.

(ii) Identifying the Artemisia species responsible for the local airborne pollen load. 


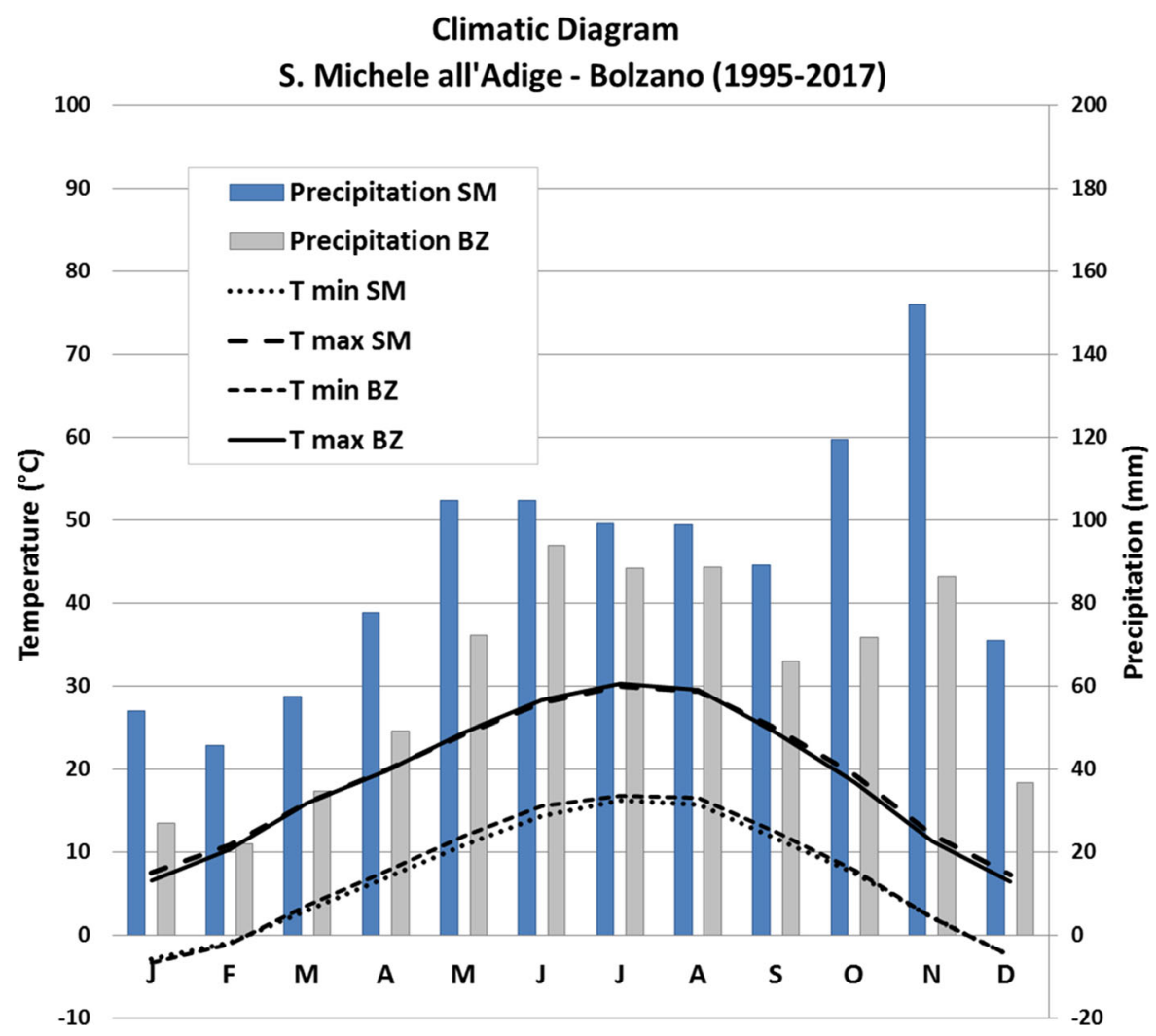

Fig. 2 Climatic diagrams (Walter's climograms) of San Michele all'Adige (blue) and Bolzano (gray). The average, over the period $1995-2017$, of daily minimum $\left(T \min ;{ }^{\circ} \mathrm{C}\right)$ and

\section{Materials and methods}

\subsection{Study sites}

The two study sites of San Michele all'Adige (SM, in Trentino; $206 \mathrm{~m}$ a.s.1.; Lat. 46.1900722-Long. 11.1346308) and Bolzano (BZ, in Alto Adige; 272 m a.s.l.; Lat. 46.4995001-Long. 11.3420856) are located on the Adige valley floor (Trentino-Alto Adige region, Northern Italy), $38 \mathrm{~km}$ away from each other (Fig. 1). As shown by the climatic diagrams (Fig. 2), the meteorological conditions at the two sites are similar. Minimum and maximum temperatures show the same pattern along the year: January is the coolest month (mean minimum temperature BZ: $-3.3{ }^{\circ} \mathrm{C}$; SM: $-2.9^{\circ} \mathrm{C}$ ), and July is the hottest one (mean maximum temperature BZ: $30.3{ }^{\circ} \mathrm{C}$; SM: $30.0{ }^{\circ} \mathrm{C}$ ). As expected in an Alpine area (Isotta et al. 2014), precipitation shows a large variation between the two sites, due to the complex topography of the region. maximum temperature $\left(T \max ;{ }^{\circ} \mathrm{C}\right)$, and of the monthly accumulated precipitation $(\mathrm{mm})$ are reported

The monthly cumulative rainfall is always higher in San Michele all'Adige, even if the pattern is comparable with that of Bolzano. Data were collected by the meteorological station closest to each aerobiological site (within a $1.5 \mathrm{~km}$ radius).

The aerobiological samplers are located within the urban areas in both locations. The surroundings are mainly cultivated by vineyards and apple orchards, where pellitory and Artemisia can be found. Broadleaf and mixed forest dominate (Orneto-Ostryetum, Quercetum pubescentis) on the lateral slopes, leaving the pace to coniferous forests as the altitude increases.

Among the herbaceous species present in the surroundings of the two study sites, the Artemisia spp. represent a relevant component of the ruderal and pioneer flora. Ten out of the twenty Artemisia species listed for Italy grow in Trentino-Alto Adige: four are rare, mountainous-sub-alpine and alpine species (i.e., above $1000 \mathrm{~m}$ a.s.l.) and six are more common and grow at the bottom of the valleys (Table 1). The latter, 
Table 1 Artemisia species list for Italy (Pignatti 2018). The presence of the autochthonous species (A) and exotic species (E) is indicated (Prosser 2019, Wilhalm 2006) as well as the percentage of quadrants (total \# 474) where the species was surveyed in Trentino and Alto Adige (FloraFaunaAltoAdige) sub-regions. The altitudinal distribution of each species is reported as gray blocks (light gray: rare; Aeschimann 2004): foothill $(\mathrm{F})$, montane $(\mathrm{M})$, subalpine (S), alpine (A) and nival (N). Flowering months are also shown: August (A), September $(\mathrm{S})$, October $(\mathrm{O})$, and November $(\mathrm{N})$

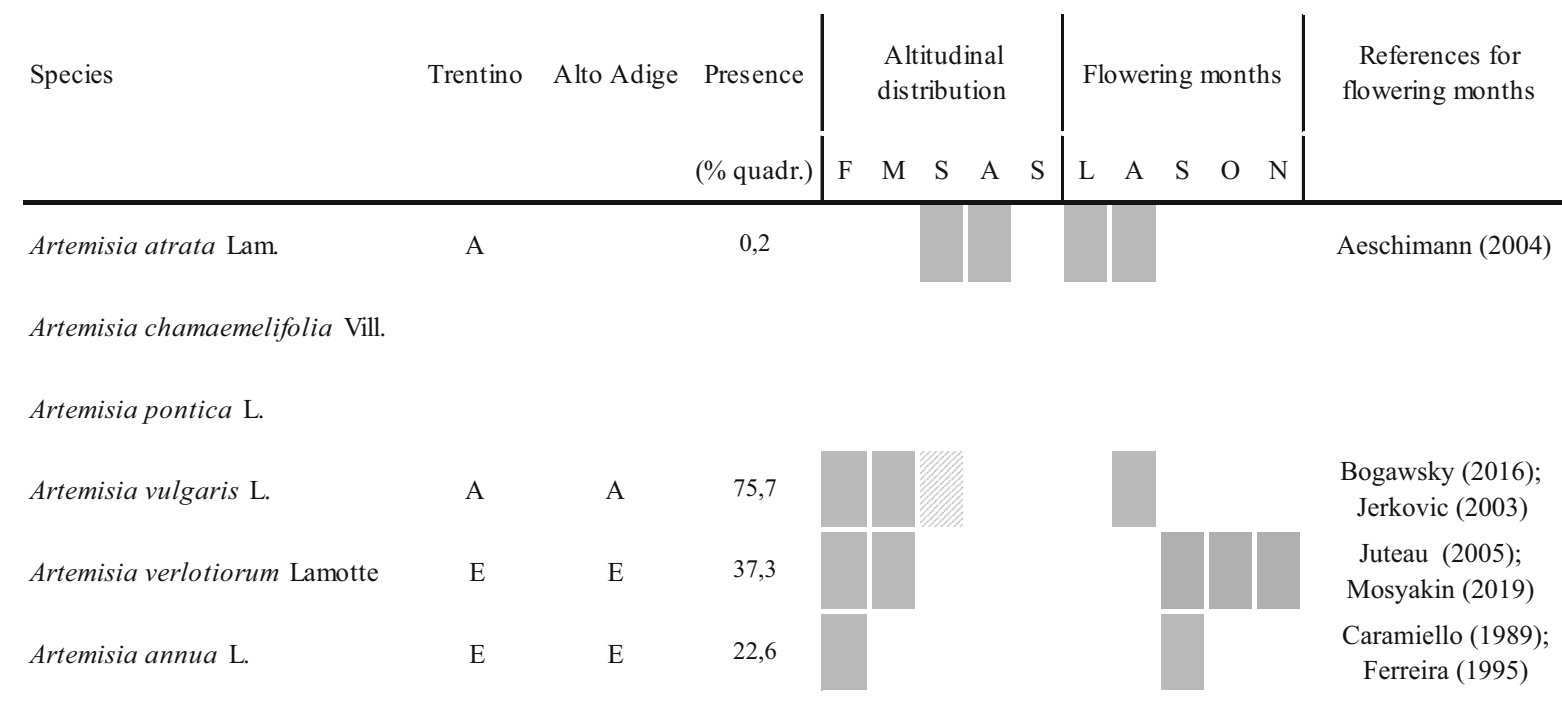

Artemisia biennis Willd.

Artemisia tournefortiana Rchb.

Artemisia umbelliformis Lam.

A

A

28,7

Artemisia genipi Stechm.

A

A

26,8

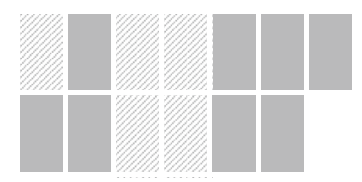

Aeschimann (2004)

Aeschimann (2004)

Artemisia pedemontana Balb.

Artemisia nitida Bertol.

A

A

9,5
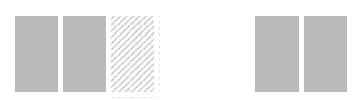

http://dryades .units.it

Artemisia glacialis L.

Artemisia absinthium L.

A

A

53,8

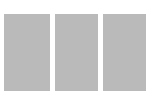

Bogawsky (2016)

Artemisia arborescens L.

Artemisia alba Turra

A

A
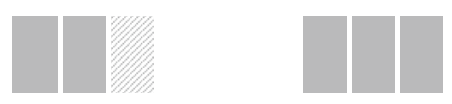

Trendafilova (2018); Aeschimann (2004)

Artemisia caerulescens L.

Artemisia vallesiaca All.

Artemisia campestris L.

A

A

40,3

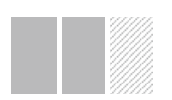

Bogawsky (2016) 
in decreasing order of abundance, expressed as percentage of quadrants where the species were surveyed, are: A. vulgaris, A. absinthium, A. campestris, A. verlotiorum, A. annua and $A$. alba. These six species were further considered for this study, giving the high probability that Artemisia pollen collected in both aerobiological monitoring sites of $\mathrm{SM}$ and BZ belongs to them; four of the six species are native and two exotic (i.e., A. annua and A. verlotiorum). Flowering and pollen release of $A$. vulgaris, $A$. absinthium, A. campestris and A. alba occur in August, while it happens later, mainly in September and October, for the two invasive species A. verlotiorum and $A$. аппиа, and, partly, also continues for the native A. alba (for details see Table 1).

Figure 1 shows the spatial distribution of $A$. vulgaris, the most common native species in the Trentino-Alto Adige region (see Table 1), and of the invasive species $A$. апnиa and $A$. verlotiorum, widespread at the valley bottom.

\subsection{Artemisia spp. pollen morphology}

Fresh pollen was collected from inflorescences of $A$. vulgaris, the most common native species in the Trentino-Alto Adige region, and of the invasive species A. апnиa and A. verlotiorum, during the period of full flowering. Reference slides were prepared to examine the main morphological characteristics of the pollen grains of each species at light microscopy. Measurement of the polar axis and the diameter of the equatorial plane were taken on $n=50$ (discretional number) pollen grains per species using an oil immersion $100 \times$ objective. Concurrently, some polar and equatorial view pictures of optimal colored pollen grains were taken.

\subsection{Aerobiological monitoring}

Daily airborne pollen concentration data from 1995 to 2019 were obtained by means of two volumetric Hirsttype samplers. The sampler installed in San Michele all' Adige (TN) is located on the top of a 10-m pole; the sampler installed in Bolzano is located on the rooftop of the Agency for Environment and Climate Protection, about $24 \mathrm{~m}$ above ground level. In both locations, sampling was carried out continuously from 1995 to 2019. The sampling and analysis of airborne pollen were performed following a standard procedure (UNI
EN 16868:2019). Particle identification and counting was carried out by light microscopy at $400 \times$ magnification along homogeneously distributed longitudinal sweeps on the slide and considering $10-17 \%$ of the sampling surface. Samples were examined by trained operators for Artemisia pollen species identification. Reference slides, prepared from ad hoc collected pollen grains of the prevalent local Artemisia species, (i.e., A. vulgaris, A. апnиa, A. verlotiorum; see Sect. 2.2), were useful for this purpose.

\subsection{Data analysis}

Daily pollen concentrations, obtained from the monitoring data for each year, were checked for completeness. As a first step, any gaps were filled by using the moving mean method to deal with missing data (Rojo et al. 2019a, b). The start and end days of the pollen season (days when $2.5 \%$ and $97.5 \%$ of the annual pollen integral (APIn) were reached, respectively) were determined using the $\mathrm{R}$ package AeRobiology (Rojo et al. 2019a, b), calculating the average date and standard deviation. Within the Artemisia mean pollen season (2.5-97.5\% of APIn) ( \pm standard deviation, SD), obtained from the first step, each year was searched for raw missing data (Supplemental Table 1). When the completeness of a pollen season was lower than $80 \%$ of days with pollen data, pollen data for that year were discarded: that happened in one case only, the year 2010 in SM. Maximum daily mean concentrations (peak values) were determined for the first and the second flowering period separately. When the same value of maximum concentration was reached on more than one date, the first one was arbitrarily considered as the peak day for further processing. The presence of a monotonic trend for annual data was evaluated by the Mann-Kendall test, and the slope of the linear trend was calculated by Sen's estimate (MAKESENS 1.0 version freeware, Finnish Meteorological Institute). The presence of a point-change was verified by the Pettitt test (Pettitt 1979). The significance of the difference in pollen concentration before and after the change-point was analyzed by the two-sample Kolmogorov-Smirnov test [Statistica (data analysis software system), version 13, TIBCO Software Inc., 2017; https://statistica.io]. 
Table 2 Artemisia pollen season descriptors: mean annual pollen integral (API), season start and end dates, season length, first and second peak concentration and related dates, for Bolzano and San Michele all'Adige. Data were averaged over the 1994-2019 period (2010 was excluded for San Michele
all'Adige). Pollen concentration values are expressed in pollen per cubic meter of air $\left(\mathrm{P}^{*} \mathrm{~m}^{-3}\right)$; dates are expressed in day of year (DOY); standard deviation (sd) was calculated for each value

\begin{tabular}{|c|c|c|c|c|}
\hline \multirow[t]{2}{*}{ Pollen season descriptor } & \multicolumn{2}{|c|}{ Bolzano $(n=25)$} & \multicolumn{2}{|c|}{ San Michele all'Adige $(n=24)$} \\
\hline & Mean & $\mathrm{Sd}$ & Mean & $\mathrm{Sd}$ \\
\hline Annual pollen integral, $\mathrm{P}^{*} \mathrm{~m}^{-3}$ & 537 & 188 & 1178 & 497 \\
\hline Season start date $(2.5 \%)$, DOY & 215 & 4 & 218 & 3 \\
\hline Season end date $(97.5 \%)$, DOY & 287 & 9 & 279 & 6 \\
\hline Season length, n. of days & 72 & 13 & 61 & 9 \\
\hline First peak concentration, $\mathrm{P}^{*} \mathrm{~m}^{-3}$ & 32 & 22 & 86 & 47 \\
\hline First peak date, DOY & 227 & 3 & 228 & 3 \\
\hline Second peak concentration, $\mathrm{P}^{*} \mathrm{~m}^{-3}$ & 30 & 11 & 78 & 90 \\
\hline Second peak date, DOY & 267 & 3 & 267 & 2 \\
\hline
\end{tabular}

\section{Results}

The pollen season of Artemisia has a very consistent start throughout the years: the start date is set, on average, on the 215th day of the year (August $1 \pm 4$ days) in BZ and on the 218th day (August $4 \pm 3$ days) in SM. The season lasts for an average of 72 ( \pm 13 ) days in BZ and $61( \pm 9)$ days in SM. The annual pollen integral has a high inter-annual variability in both sites, with the mean value in SM $\left(1178 \pm 497 \mathrm{P}^{*} \mathrm{~m}^{-3}\right)$ double than in $\mathrm{BZ}$ $\left(537 \pm 188 \mathrm{P}^{*} \mathrm{~m}^{-3}\right)$ (Table 2).

The pollen calendar shows two main peaks occurring consistently in both study sites, with decreasing values for the first peak and increasing values for the second peak at both sites, along the 25-year time span (Fig. 3). The first peak occurs, on average, on the 227th day of the year (August $13 \pm 3$ days) in BZ and on the 228th (August $14 \pm 3$ days) in SM. The second peak was recorded on average on the 267th day of the year at both sites (September $22 \pm 3$ days for BZ and \pm 2 days for SM) (Table 2). The time trend of the peak values of the Artemisia pollen concentration for the two sites is shown in Fig. 4. Both peak concentrations show a clear trend over the study period: the first peak concentration in August tends to decrease significantly $(p<0.001)$ during the study period for $\mathrm{BZ}$, while the second peak shows a significant increase both for $\mathrm{BZ}(p<0.05)$ and $\mathrm{SM}(p<0.001)$ site, where it is very marked. A change-point with a marked statistically significant difference in pollen concentration before and after the change-point $(p<0.001)$ was found for BZ's first peak in 2002 and for the second peak of SM in $2011(p<0.001)$, while in BZ the change point of the second peak was observed in 2007 $(p<0.05$; Table 3$)$.

Based on flowering phase, altitudinal distribution, and abundance of the local species (see Table 1), A. vulgaris can be reasonably considered one of the main source of Artemisia pollen for the August peak, while the second peak seems mainly attributable to $A$. аппиа and $A$. verlotiorum, as reported for other regions of Northern Italy (Caramiello et al. 1989).

Figure 5 shows the inflorescences and pollen grains of Artemisia vulgaris, A. annua and A. verlotiorum in equatorial and polar view. Table 4 details the pollen dimension of these three Artemisia species, utilized as a benchmark for the morphological discrimination of Artemisia pollen grains at the light microscope. Since A. verlotiorum pollen displays a peculiar bigger size in comparison with the other species, it was possible to define, for the second peak, the frequency of $A$. verlotiorum vs. the other Artemisia species (mainly represented by A. аnnua). The results, expressed as the percentage of $A$. verlotiorum pollen grains out of the total Artemisia pollen of the second peak, are shown in Fig. 6, for each year and site considered. The contribution of $A$. verlotiorum to the second peak of Artemisia pollen concentration does not show any 

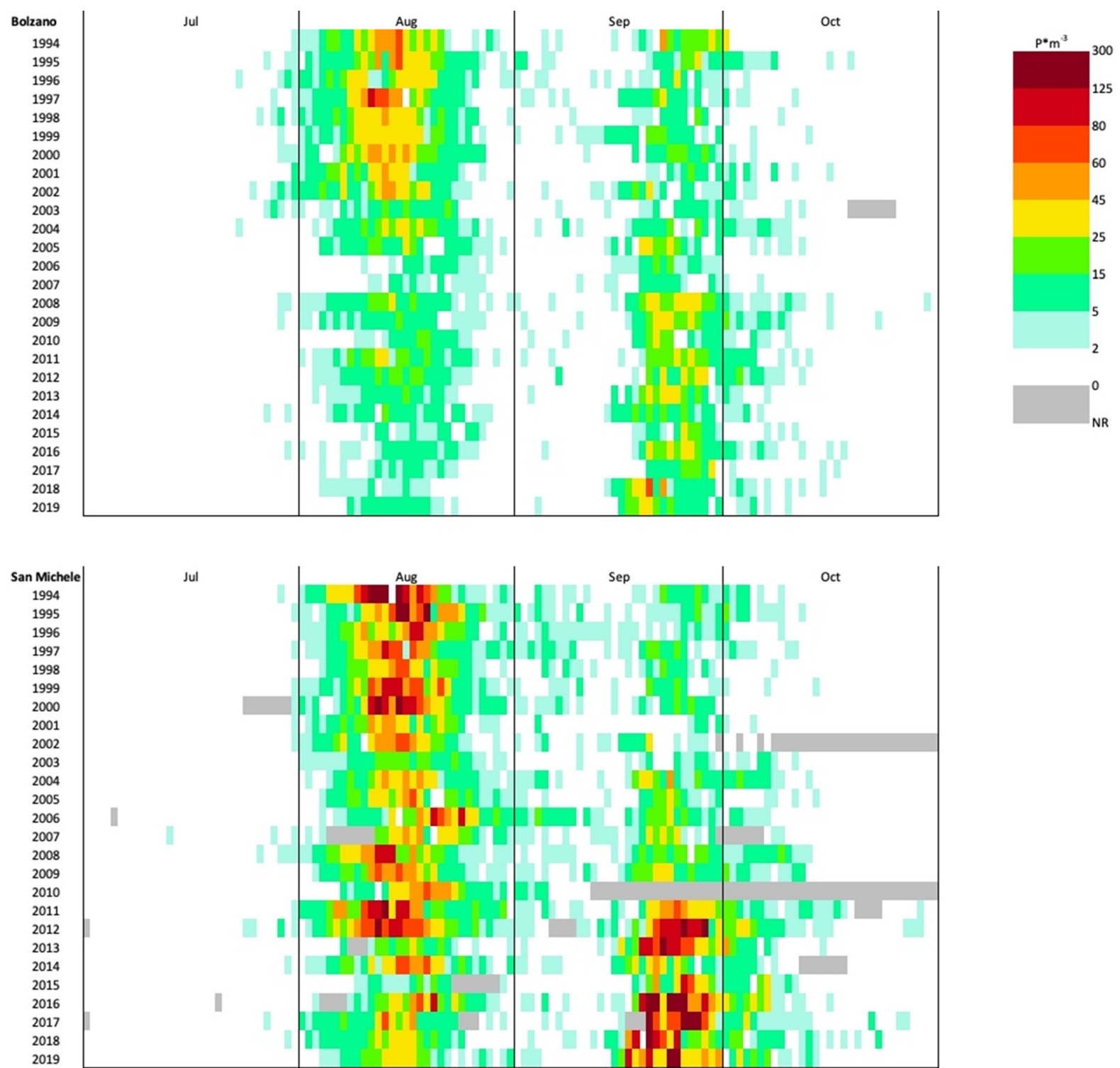

Fig. 3 Artemisia pollen calendar for San Michele all'Adige (1994-2019, 2010 excluded) and Bolzano (1994-2019). The color classes were defined calculating quantiles from the pool of daily pollen concentration (1994-2019), expressed in $\mathrm{P}^{*} \mathrm{~m}^{-3}$, of both study sites, excluding zero and missing values. The resulting quantiles, exception made for the lowest, were approximated to the closest multiple of five. The data of the

linear trend over the time period considered, for both sites, as verified by the Mann-Kendall test $(p>0.05)$. study site of Bolzano were used for the lower color classes; in particular, 2 is the 0.5 quantile, 15 is the 0.9 quantile, 25 is the 0.95 quantile, and 45 is the 0.99 quantile. For the upper part of the color classes, the data set of the study site of San Michele all'Adige was used; in particular, 60 is the 0.95 quantile, 80 is the 0.975 quantile, and 125 is the 0.99 quantile

\section{Discussion}

The ongoing global and climate changes, among other factors, are promoting the expansion of neophytes and influencing plant phenology. In the northern hemisphere, these changes are resulting in a prolonged 

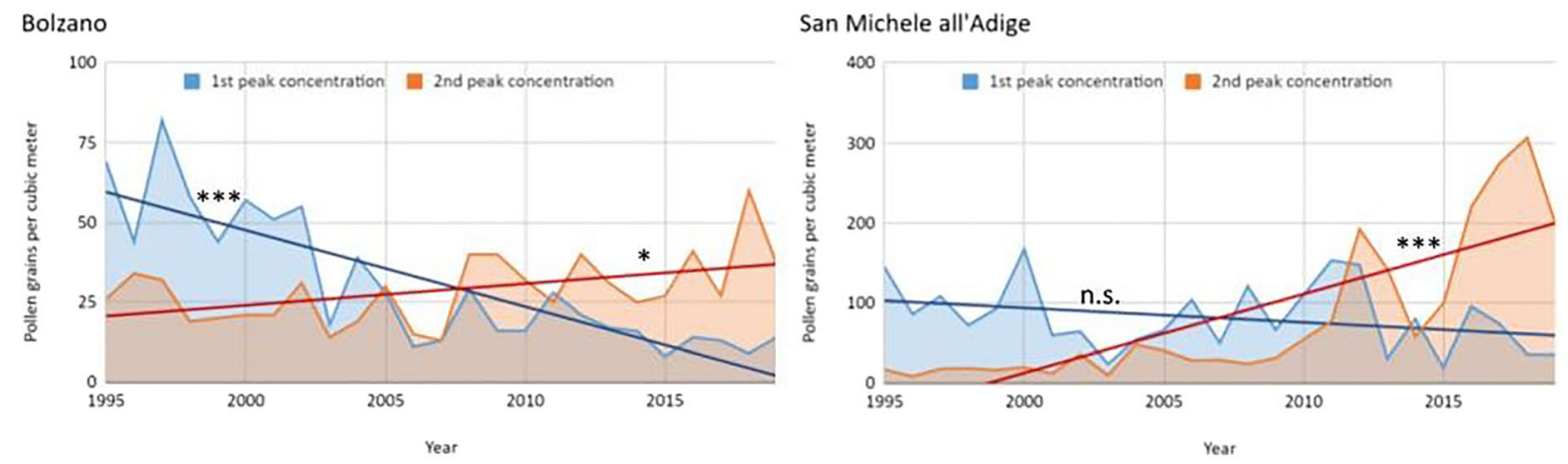

Fig. 4 Peak concentrations of Artemisia pollen during the 25-year study period for the two peaks and sites (Bolzano and San Michele all'Adige). The linear trend is reported in case of statistical significance ( $*=p<0.05 ; * * *=p<0.001$; see Table 3 for details)

Table 3 Results of nonparametric statistics to test the monotonic trend for annual data (Mann-Kendall trend test), the slope of the linear trend (Sen's slope estimate), the presence of a change-point (Pettitt change point), and the significance of the difference in the pollen concentration before and after the change-point (Kolmogorov-Smirnov) for the two peak concentrations and the two periods (January-August and September-December $)$ in Bolzano $(\mathrm{n}=25)$ and San Michele all'Adige $(n=24)$

\begin{tabular}{|c|c|c|c|c|c|c|}
\hline & \multicolumn{3}{|c|}{ Mann-Kendall trend test } & \multirow{2}{*}{$\begin{array}{l}\text { Sen's slope } \\
\text { estimate } \\
Q\end{array}$} & \multirow{2}{*}{$\begin{array}{l}\text { Pettitt change } \\
\text { point } \\
\text { Year }\end{array}$} & \multirow{2}{*}{$\begin{array}{l}\text { Kolmogorov- } \\
\text { Smirnov } \\
p \text { value }\end{array}$} \\
\hline & $\mathrm{Z}$ & $p$ value & Significance & & & \\
\hline \multicolumn{7}{|l|}{ PIn Jan-Aug } \\
\hline Bolzano & -4.69 & $p<0.001$ & $* * *$ & -22.26 & 2004 & $p<0.001$ \\
\hline San Michele all'Adige & -2.46 & $p<0.05$ & $*$ & -21.26 & 2012 & $p<0.05$ \\
\hline \multicolumn{7}{|l|}{ First peak concentration } \\
\hline Bolzano & -4.59 & $\begin{array}{r}p<0 \\
.001\end{array}$ & $* * *$ & -2.30 & 2002 & $p<0.001$ \\
\hline San Michele all'Adige & 1.51 & $p>0.05$ & n.s & -1.95 & 2012 & $p>0.05$ \\
\hline \multicolumn{7}{|l|}{ PIn Sept-Dec } \\
\hline Bolzano & 2.41 & $p<0.01$ & $* *$ & 5.84 & 2007 & $p<0.05$ \\
\hline San Michele all'Adige & 4.44 & $p<0.001$ & $* * *$ & 41.75 & 2009 & $p<0.001$ \\
\hline \multicolumn{7}{|c|}{ Second peak concentration } \\
\hline Bolzano & 2.23 & $p<0.05$ & $*$ & 0.47 & 2007 & $p<0.05$ \\
\hline San Michele all'Adige & 4.84 & $p<0.001$ & $* * *$ & 6.68 & 2011 & $p<0.001$ \\
\hline
\end{tabular}

pollen season (Ziska 2016) and in variations in the temporal pattern of the airborne pollen season. Respiratory allergies represent a global health issue, and pollen is considered one of the important risk factors for allergic diseases (Pawankar et al. 2013). Artemisia pollen grains are recognized as a relevant source of aeroallergens worldwide, with a distinct allergenicity for the different species of the genus, influenced both by genetic and environmental (e.g., weather and pollution) factors (Grewling et al. 2020). In
Trentino-Alto Adige (Northern Italy), where the present study was carried out, the aerobiological data for the last 25 years indicate an increase of the Artemisia pollen load in the air, occurring since September (Fig. 7). This Artemisia pollen fraction is mostly ascribable to the late flowering species $A$. аппиа and $A$. verlotiorum, two invasive allochthon species widely distributed in the study area, candidates to be responsible of the pollen allergic symptoms at the end of the yearly pollen season. 


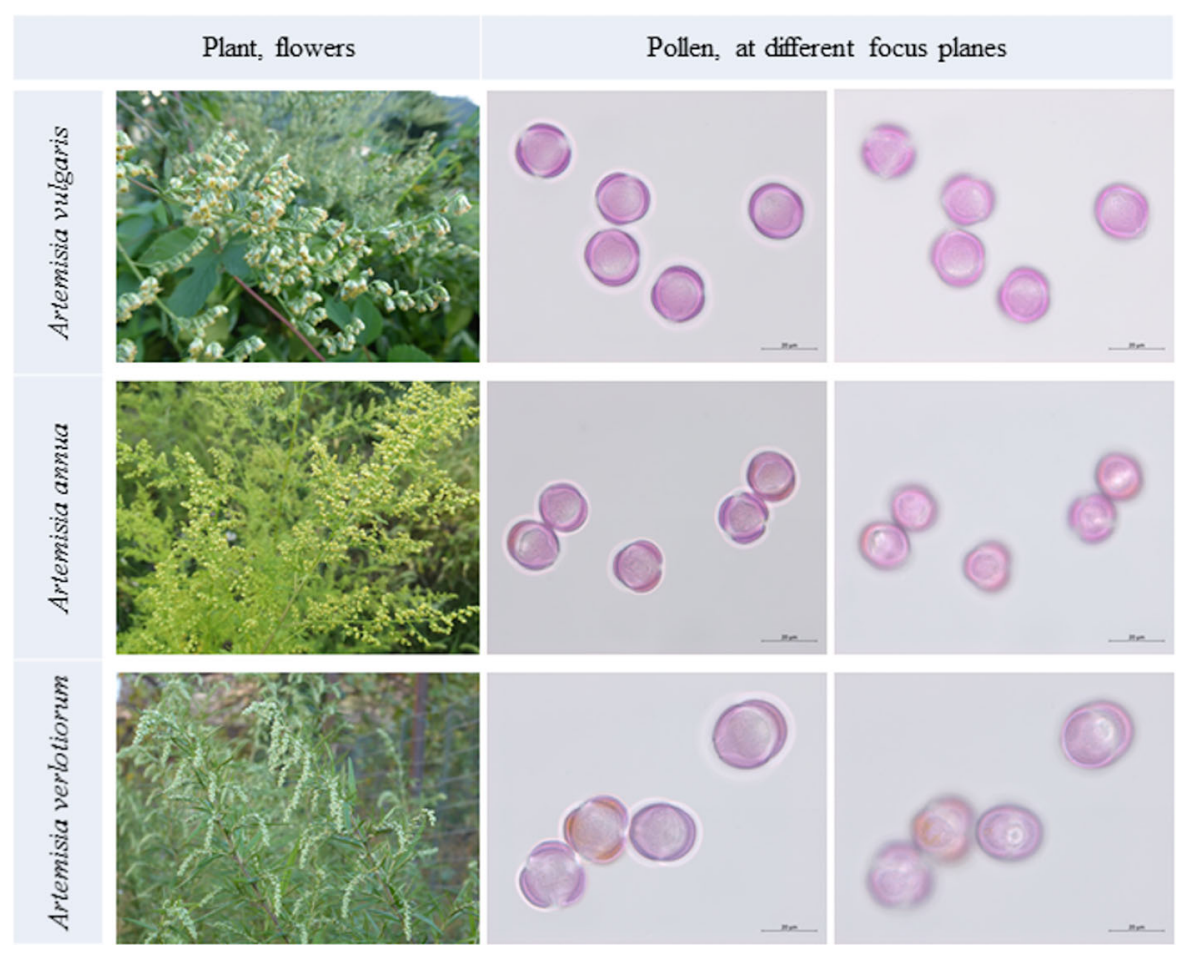

Fig. 5 Inflorescences and pollen grains in equatorial and polar views. The pollen grains were colored with fuchsine, observed under the light microscope and photographed with an objective 100x (oil immersion) at different focal planes to highlight the characteristic structure of the pollen wall in optical section, as

A. аппиа is an annual plant and grows typically on ruderal sites. It readily uses available nutrients to increase biomass and invests in seed production; furthermore, it shows a remarkable phenotypic plasticity. Shoot length can reach up to over two meters, but even the smallest individuals reproduce (Müller and Brandes, 1997). A. verlotiorum is a perennial plant that colonizes disturbed sites, and it does not seem to depend on seed production for a successful propagation. Although under favorable conditions the species reaches the flowering and fruiting stages, it produces numerous vegetative shoots and spreads mainly by rhizome fragments. Once introduced, A. verlotiorum is hard to eradicate due to its stoloniferous rhizomes (Mosyakin et al. 2019, Gabrielian and Vallès 1996). The vegetative propagation offers $A$. verlotiorum a reproductive advantage, promoting the invasion of the ecological niche of A. vulgaris. Although first records of $A$. апnиa and A. verlotiorum plants in Trentino-Alto Adige region go back at the beginning of the last century (Prosser et al. 2019), recent botanical well as the elements of ornamentation (microechinate) on the pollen surface. A. verlotiorum has its inflorescences directed all to one side and its pollen is evidently larger compared to the contemporaneously flowering species $A$. аппиа

observations evidenced that the spread of the two invasive species has considerably increased in the last three decades (Supplemental Table 2). This trend is in agreement with and confirms the aerobiological data that show the concurrent rise of pollen concentrations of the Artemisia species.

Even if both $A$. аnnua and A. verlotiorum are largely distributed in the region, the pollen peak concentrations sampled in September-October show low frequencies of $A$. verlotiorum pollen grains. This could be due to the high pollen production of $A$. аппи and to the smaller pollen size when compared to $A$. verlotiorum one, resulting in a better floating ability and therefore to a higher presence in the atmospheric layer of the sampler (i.e., $10 \mathrm{~m}$ above the ground). Nevertheless, when we consider the lower levels, where humans breathe, A. verlotiorum might be a locally important pollen source for pollen allergy sufferers, especially for, e.g., farm workers in the apple and grape orchards, where this species is frequently growing. 


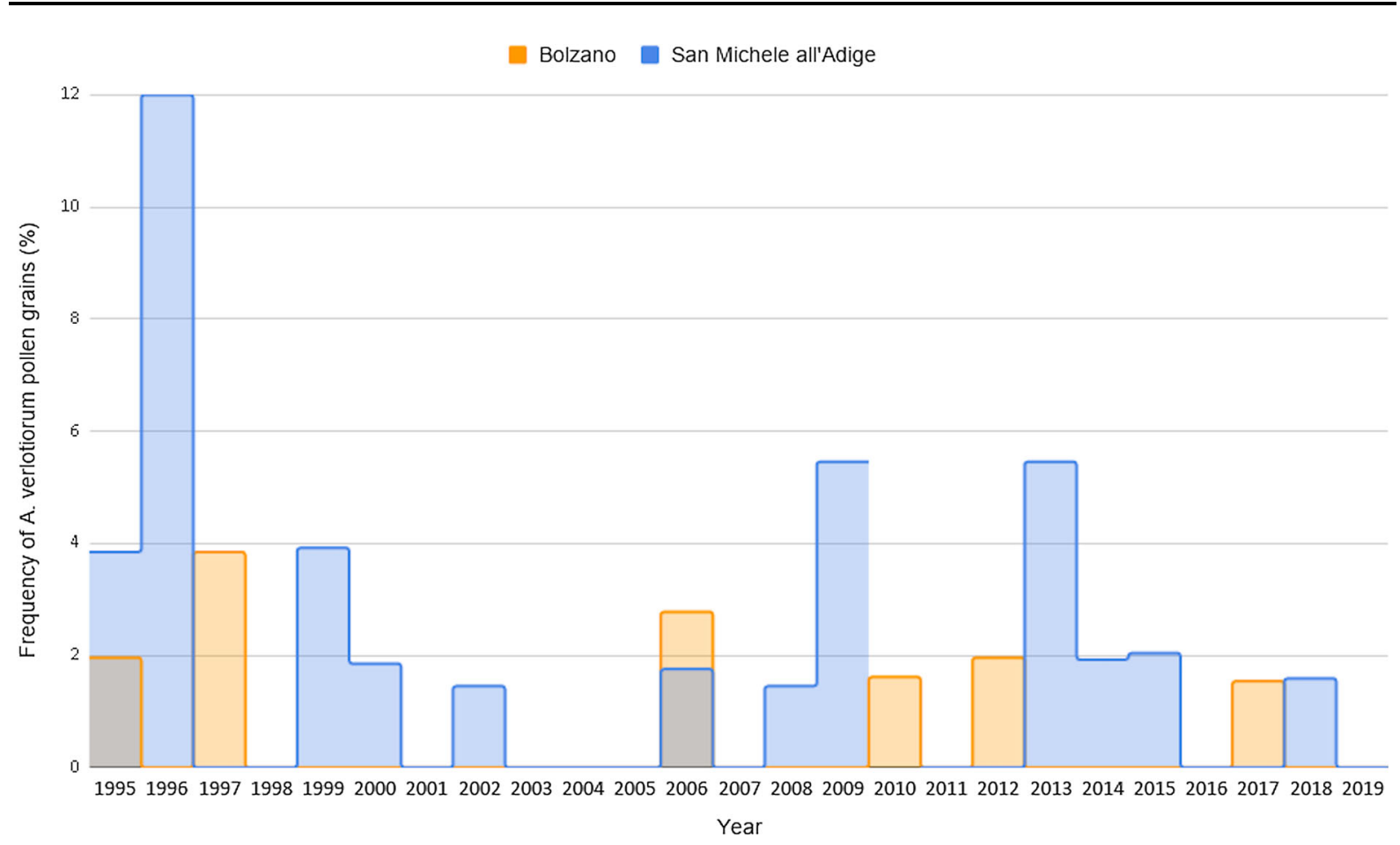

Fig. 6 Contribution of Artemisia verlotiorum to the late Artemisia pollen peak concentrations in September for each year from 1995 to 2019, expressed in percentage versus the other Artemisia species. No significant linear trend was revealed for the two study sites

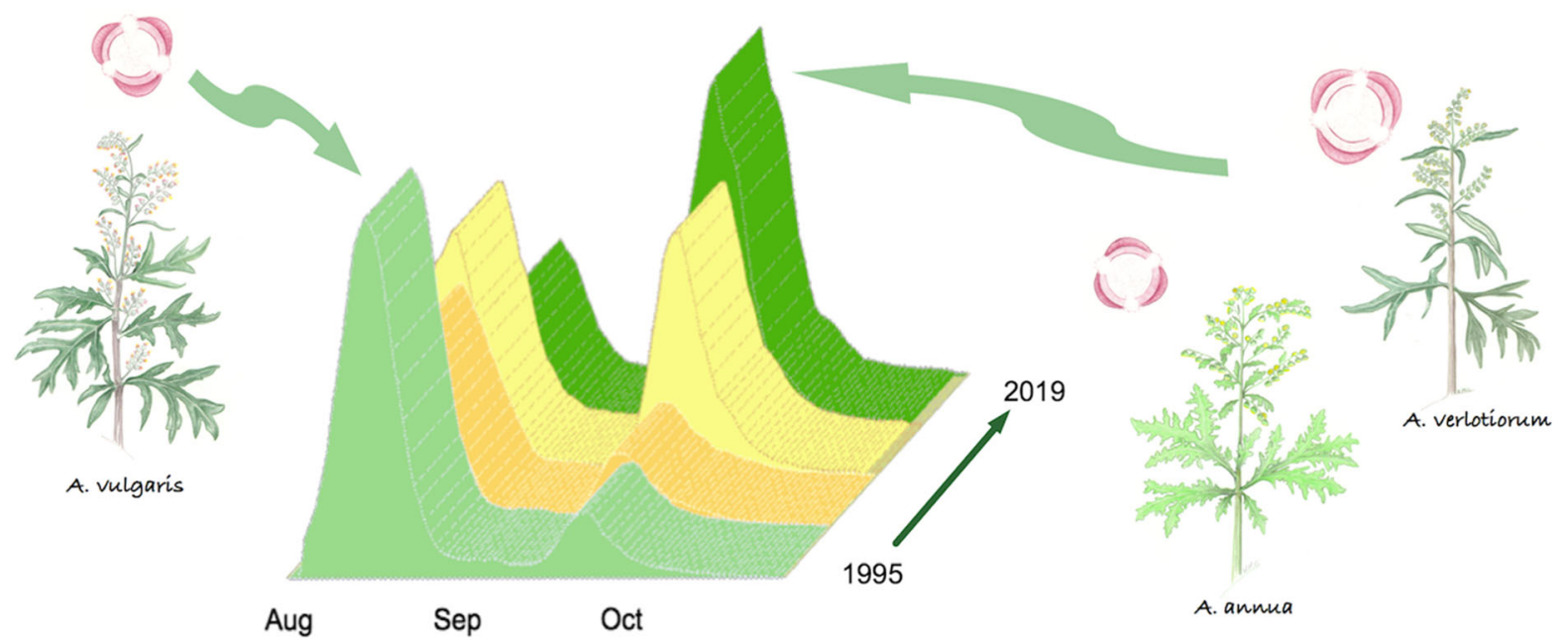

Fig. 7 Infographic conceptual map illustrating the main results. The increase of Artemisia late summer pollen in the air is evident for recent years. The association of the target Artemisia species to the two peaks of concentration is illustrated by hand painting 
Table 4 Descriptive statistic [mean, standard deviation (sd), minimum and maximum length of equatorial diameter and polar axis] of pollen grains collected from the three selected Artemisia species growing in Trentino-Alto Adige (North Italy)

\begin{tabular}{|c|c|c|c|}
\hline & \multicolumn{2}{|c|}{ Equatorial diameter, um $(n=50)$} & \multirow{2}{*}{$\begin{array}{l}\text { Polar axis, um }(\mathrm{n}=50) \\
\text { Mean } \pm \mathrm{sd}\end{array}$} \\
\hline & Mean \pm sd & Min-max & \\
\hline Artemisia vulgaris & $21.3 \pm 0.9$ & $18.9-23.0$ & $19.6 \pm 0.7$ \\
\hline Artemisia аппиа & $20.0 \pm 1.1$ & $17.2-22.8$ & $17.3 \pm 0.7$ \\
\hline Artemisia verlotiorum & $26.5 \pm 1.7$ & $22.0-29.8$ & $22.6 \pm 1.2$ \\
\hline
\end{tabular}

\section{Conclusions}

In the last few decades, Trentino-Alto Adige region (Northern Italy) has been experiencing a large increase of late season Artemisia pollen concentrations, mainly due to the spread of Artemisia annua and, to a lower extent, of A. verlotiorum, both allochthon invasive species flowering during September and October.

Giving the allergenicity of Artemisia pollen, the expansion of Artemisia species could affect human health, by exacerbating allergic symptoms in autumn. In addition, from an ecological point of view, the spread of invasive species such as A. verlotiorum and A. аппиа may threaten plant biodiversity in both natural and cultivated areas, with negative impacts on, e.g., Natura 2000 protected sites (e.g., riparian habitats) and crops. All these factors should be carefully considered in pollen monitoring and forecasting, in order to deliver appropriate and timely information on the airborne pollen load, and to adopt effective environment management measures to limit the spread of these troublesome invasive species.

Acknowledgements We thank Maria Cristina Viola (Fondazione Edmund Mach) for her precious help in fieldwork, slide analysis and for the botanical drawings. We are also grateful to Thomas Wilhalm (Museum of Nature South Tyrol, Bolzano) for the data about the distribution of Artemisia species in Alto Adige and to Luca Delucchi (Fondazione Edmund Mach) for the Trentino-Alto Adige altitudinal raster image. We are grateful for the suggestions of the reviewers, who contributed to ameliorate the manuscript.

Open Access This article is licensed under a Creative Commons Attribution 4.0 International License, which permits use, sharing, adaptation, distribution and reproduction in any medium or format, as long as you give appropriate credit to the original author(s) and the source, provide a link to the Creative Commons licence, and indicate if changes were made. The images or other third party material in this article are included in the article's Creative Commons licence, unless indicated otherwise in a credit line to the material. If material is not included in the article's Creative Commons licence and your intended use is not permitted by statutory regulation or exceeds the permitted use, you will need to obtain permission directly from the copyright holder. To view a copy of this licence, visit http://creativecommons.org/licenses/by/4.0/.

Funding Open access funding provided by Fondazione Edmund Mach - Istituto Agrario di San Michele all'Adige within the CRUI-CARE Agreement.

\section{References}

Aeschimann, D., Lauber, K., Moser, D.M., Theurillat, J.P. (2004) Flora Alpina. ed. Zanichelli ISBN-10: 8808071596

Banfi, E., \& Galasso, G. (2010). La flora esotica Lombarda. Milano, Italy: Regione Lombardia e Museo storia Naturale di Milano.

Bogawski, P., Grewling, Ł., \& Frątczak, A. (2016). Flowering phenology and potential pollen emission of three Artemisia species in relation to airborne pollen data in Poznań (Western Poland). Aerobiologia, 32, 265-276. https://doi. org/10.1007/s10453-015-9397-z.

Burbach, G. J., Heinzerling, L. M., Edenharter, G., Bachert, C., Bindslev-Jensen, C., Bonini, S., et al. (2009). GA2LEN skin test study II: clinical relevance of inhalant allergen sensitizations in Europe. Allergy, 64(10), 1507-1515. https://doi.org/10.1111/j.1398-9995.2009.02089.x.

Caramiello, R., Siniscalco, C., \& Polini, V. (1989). Analyses aeropalynologiques, morphometriques et phenologiques d'Artemisia. Grana, 28, 105-113. https://doi.org/10.1080/ 00173138909429961.

Cariñanos P., Alcázar P., de la Corte E., Díaz de la Guardia C., González Minero F., Hidalgo P.J., Recio M., Ruiz L., del Mar Trigo M., Ogalla V.M., Orihuela C., Galán C. (2010). Aerobiology and Biogeography of Genus Artemisia in Andalucia. Conference: 9th International Congress on Aerobiology, Volume: International Association for Aerobiology Buenos Aires, Argentina, Vol. 31.

Cariñanos, P., Díaz de la Guardia, C., Algarra, J., De Linares, C., \& Irurita, J. (2013). The pollen counts as bioindicator of meteorological trends and tool for assessing the status of endangered species: the case of Artemisia in Sierra Nevada (Spain). Climatic Change, 119, 799-813. https://doi.org/ 10.1007/s10584-013-0751-2. 
Fernández-Llamazares, Á., Belmonte, J., Boada, M., \& Fraixedas, S. (2014). Airborne pollen records and their potential applications to the conservation of biodiversity. Aerobiologia, 30, 111-122. https://doi.org/10.1007/s10453-0139320-4.

Ferreira, J., Simon, J., \& Janick, J. (1995). Developmental Studies of Artemisia annua : Flowering and Artemisinin Production Under Greenhouse and Field Conditions Planta Medica. Planta Medica, 61(2), 167-170. https://doi.org/ 10.1055/s-2006-958040.

FloraFaunaAltoAdige. Il portale sulla distribuzione delle specie animali e vegetali in Alto Adige, Museo di Scienze Naturali dell'Alto Adige, Bolzano. Accessed 8 November 2019, from www.florafauna.it.

Gabrielian, E., \& Vallès, X. J. (1996). New data about the genus Artemisia L. (Asteraceae) in Armenia. Willdenowia, 26, 245-250. https://doi.org/10.3372/wi.26.2611.

Gao, Z., Fu, W. Y., Sun, Y. M., Gao, B. Y., Wang, H. Y., Liu, M. L., et al. (2019). Artemisia pollen allergy in China: Component-resolved diagnosis reveals allergic asthma patients have significant multiple allergen sensitization. Allergy, 74, 284-293. https://doi.org/10.1111/all.13597.

Giner, M. M., García, J. C., \& Sellés, J. G. (1998). Winter blooming of Artemisia. A 2-year survey in murcia (Spain). Aerobiologia, 14, 109. https://doi.org/10.1007/ BF02694194.

Grewling, Ł., Bogawski, P., Kostecki, Ł., Nowak, M., Szymańska, A., \& Frątczak, A. (2020). Atmospheric exposure to the major Artemisia pollen allergen (Art v 1): Seasonality, impact of weather, and clinical implications. Science of The Total Environment, 713, 136611. https://doi.org/10. 1016/j.scitotenv.2020.136611.

Grewling, Ł., Kasprzyk, I., Borycka, K., Chłopek, K., Kostecki, Ł., Majkowska-Wojciechowska, B., et al. (2015). Searching for a trace of Artemisia campestris pollen in the air. Acta Agrobotanica, 68(4), 399-404. https://doi.org/10. 5586/aa.2015.040.

Grewling, Ł., Šikoparija, B., Skjøth, C. A., Radišić, P., Apatini, D., Magyar, D., et al. (2012). Variation in Artemisia pollen seasons in Central and Eastern Europe. Agricultural and Forest Meteorology, 160, 48-59. https://doi.org/10.1016/j. agrformet.2012.02.013.

Isotta, F. A., Frei, C., Weilguni, V., Perčec Tadić, M., Lassègues, P., Rudolf, B., et al. (2014). The climate of daily precipitation in the Alps: Development and analysis of a high-resolution grid dataset from pan-Alpine rain-gauge data. International Journal of Climatology, 34(5), 1657-1675. https://doi.org/10.1002/joc.3794.

Jerkovic, I., Mastelic, J., Milos, M., Juteau, F., Masotti, V., \& Viano, J. (2003). Chemical variability of Artemisia vulgaris L. essential oils originated from the Mediterranean area of France and Croatia. Flavour and Fragrance Journal, 18(5), 436-440. https://doi.org/10.1002/ffj.1246.

Juteau, F., Masotti, V., \& Viano, J. (2005). Chemical variation in the oil of Artemisia verlotiorum Lamotte of French origin harwested at a vegetative stage and during flowering. Journal of Essential Oil Research, 17, 254-256.

Mosyakin, S. L., Boiko, G. V., \& Glukhova, S. A. (2019). Artemisia verlotiorum (Asteraceae) in the continental part of Ukraine: now in Kyiv. Ukrainian Botanical Journal, 76(1), 3-8. https://doi.org/10.15407/ukrbotj76.01.003.
Müller, M., \& Brandes, D. (1997). Growth and development of Artemisia annua L. on different soil types. Verhandlungen der Gesellschaft für Ökologie, 27, 453-460.

Pawankar R., Canonica G.W., Holgate S., Lockey R.F., Blaiss M.S. (2013). White book on allergy: update 2013. World Allergy Organization, Milwaukee, USA. ISBN-10: 0615929168. Accessed 16 March 2020 from, https://www. worldallergy.org/UserFiles/file/WhiteBook2-2013-v8.pdf.

Pettitt, A. N. (1979). A non-parametric approach to the changepoint detection. Applied Statistics, 28, 126-135. https://doi. org/10.2307/2346729.

Pignatti S. (2018). La flora d'Italia. ed. Edagricole-New Business Media, Milano, IT. ISBN:978-88-5065-244-0.

Piotrowska, K. (2008). Pollen production in selected species of anemophilous plants. Acta Agrobotanica, 61(1), 41-52. https://doi.org/10.5586/aa.2008.005.

Prosser F., Bertolli A., Festi F., Perazza G. (2019). Flora del Trentino. ed. Osiride. Rovereto (TN), Italy. ISBN: 978-887498-297-4.

Qin, X., Li, Y., Sun, X., Meng, L., \& Wang, X. (2019). Transport pathway and source area for Artemisia pollen in Beijing, China. International Journal of Biometeorology, 63(5), 687-699. https://doi.org/10.1007/s00484-017-1467-1.

Rojo, J., Oteros, J., Pérez-Badia, R., Cervigón, P., Ferencova, Z., Gutiérrez-Bustillo, A. M., et al. (2019a). Near-ground effect of height on pollen exposure. Environmental Research, 174(May), 160-169. https://doi.org/10.1016/j. envres.2019.04.027.

Rojo, J., Picornell, A., \& Oteros, J. (2019b). AeRobiology: The computational tool for biological data in the air. Methods in Ecology and Evolution, 10(8), 1371-1376. https://doi.org/ 10.1111/2041-210X.13203.

Spieksma, F. T. M., Frenguelli, G., Nikkels, A. H., Mincigrucci, G., Smithius, L. O. M. J., Bricchi, E., et al. (1989). Comparative study of airborne pollen concentrations in central Italy and The Netherlands: emphasis on Alnus, Poaceae, and Artemisia. Grana, 28, 25-36. https://doi.org/10.1080/ 00173138909431009.

Spieksma, F. T. M., van Noort, P., \& Nikkels, H. (2000). Influence of nearby stands of Artemisia on street-level versus roof-top-level. Aerobiologia, 16, 21-24. https://doi. org/10.1023/A:1007618017071.

Spieksma, F. T. M., \& von Wahl, P. G. (1991). Allergenic significance of Artemisia (mugwort) pollen. In G. D'Amato, F. T. M. Spieksma, \& S. Bonini (Eds.), Allergenic pollen and pollinosis in Europe (pp. 121-124). Oxford, UK: Blackwell.

Trendafilova, A., Todorovaa, M., Genovaa, V., Samuel Peterb, S., Wolframb, E., Danovaa, K., et al. (2018). Phenolic Profile of Artemisia alba Turra. Chemistry and Biodiversity.. https://doi.org/10.1002/cbdv.201800109.

UNI EN 16868:2019 (2019). Aria Ambiente - Campionamento ed analisi di pollini e spore fungine dispersi in aria per le reti di monitoraggio delle allergie - Metodo Volumetrico Hirst. CEN-CENELEC Management Centre: Avenue Marnix 17, B-1000 Brussels. Downloadble by https://store. uni.com/catalogo/catalog/product/view/id/287499/s/en16868-2019/category/3854/?__store=en\&josso_back_ to $=$ http $\% 3 \mathrm{~A} \% 2 \mathrm{~F} \% 2$ Fstore.uni.com $\% 2$ Fjosso-securitycheck.php\&josso_cmd=login_optional\&josso_ partnerapp_host=store.uni.com\&__from_store=it. 
Weryszko-Chmielewska, E., Piotrowska-Weryszko, K., Woźniak, A., Sulborska, A., Konarska, A., Dąbrowska-Zapart, K., et al. (2018). Analysis of mugwort (Artemisia) pollen seasons in selected cities in Poland in 2018. Alergoprofil., 14, 117-122. https://doi.org/10.24292/01.ap.144381218.

Wilhalm T., Niklfeld H., Gutermann W. (2006). Katalog der Gefäßpflanzen Südtirols: Veröffentlichungen des
Naturmuseums Südtirol 3, Folio Verlag, Wien, ATU. ISBN 3-85256-325-9

Ziska, L. H. (2016). Impacts of climate change on allergen seasonality. In P. J. Beggs (Ed.), Impacts of climate change on allergens and allergic diseases (pp. 92-112). Cambridge: Cambridge University Press. https://doi.org/10. 1017/CBO9781107272859.007. 